\title{
Compensation for medical incidents as a result of out-of-court conciliatory proceedings by voivodship boards
}

\author{
ROBERT SUSŁO ${ }^{1, A, B, D-F}$, MATEUSZ PAPLICKI ${ }^{2, B, D}$, ANTONI BENEDIKT ${ }^{3, B, F}$, JAROS $Ł A W ~ D R O B N I K K^{1, A, D}$ \\ ORCID ID: 0000-0002-2680-7617 ORCID ID: 0000-0002-4169-9298 ORCID ID: 0000-0003-2362-4409 ORCID ID: 0000-0001-5472-1485 \\ ${ }^{1}$ Gerontology Unit, Public Health Department, Faculty of Health Sciences, Wroclaw Medical University, Poland \\ ${ }^{2}$ Developmental Age Traumatology and Emergency Medicine Unit, Faculty of Medicine, Wroclaw Medical \\ University, Poland \\ ${ }^{3}$ WSB University in Wroclaw, Poland
}

A - Study Design, B - Data Collection, C - Statistical Analysis, D - Data Interpretation, E - Manuscript Preparation, F - Literature Search, G - Funds Collection

Summary There is a growing gap between the public's imagination of medicine's capabilities, the range of medical services really available to the average patient, and the actual results of medical procedures. Many patients feel deceived by, neglected by, or disappointed with medicine, health institutions, and medical staff. Patients' grievances result in an increasing number of legal claims in courts and politicians introduce harsher legal regulations targeting delinquent or negligent medical professionals. The aim of the article is to discuss resulting problems and available solutions. The term "defensive medicine" describes adjustments made by medical staff to their professional activities primarily to secure themselves from claims and not to benefit the patient, involving risk reduction and risk avoidance. It is estimated that medically unjustified procedures driven by fears of malpractice suits account for even as much as $20 \%$ of total healthcare costs. Primary care physicians are among the greatest contributors in that they tend to overcautiously order otherwise unneeded hospitalizations, generating significant secondary costs. In Poland, the Patient Rights and Ombudsman Act of 6 November 2008, with its 2011 amendment, introduced a new way for hospitalized patients who have suffered medical harm to seek compensation without costly, time-consuming, blame-based court proceedings. Although - unlike in courts - claimants do not need to provide decisive evidence of the claim's accuracy, but only back it up adequately, the new administrative quasi-court proceedings has not gained popularity as often it lasts longer than expected and rather low compensation proposed tend to be considered unsatisfactory by claimants.

Key words: medical errors, jurisprudence, defensive medicine.

Susło R, Paplicki M, Benedikt A, Drobnik J. Compensation for medical incidents as a result of out-of-court conciliatory proceedings by voivodship boards. Fam Med Prim Care Rev 2020; 22(3): 257-262, doi: https://doi.org/10.5114/fmpcr.2020.96923.

\section{Background}

In recent decades, European societies have been subjected to conflicting media communications: on one hand, there have been many enthusiastic announcements of medical advancements, embellished with optimistic promises of health, beauty, longevity, and cures for diseases. However, most reports carefully avoid highlighting the fact that new methods remain under development, are extremely expensive, are not covered by medical insurance, or are too advanced to be provided by individual physicians using local medical infrastructure, and thus for a number of reasons they may not be available to the average patient. What is also often omitted - a fact that apparently should be clear to everyone, but typically is not - is that there is no medical procedure that provides a $100 \%$ guarantee of full success, even when carried out skillfully and according to all regulations on a patient perfectly suited to it. On the other hand, there are numerous reports of legal proceedings involving sometimes true, though often merely alleged or insinuated, medical mistreatment, which can often seem malicious and which are frequently devoid of merit [1]. Unfortunately, such faulty communications address a public that often lacks basic knowledge of human biology and physiology - even to the extent of rendering them unable to make conscious and responsible decisions regarding their health [2]. There is a growing gap between the public's imagination of medicine's capabilities, the range of medical services really available to the average patient, and the actual outcomes of medical procedures. This results in many patients feeling deceived by, neglected by, or disappointed with medicine, health institutions, and medical staff. Moreover, the right to medical care and a healthy life is one of the foundations of the human rights system, especially in the European Union, and patients' awareness and expectations of this have increased [3]. It should consequently be expected that governments would be interested in increasing public participation in health policymaking and including policies' target groups [4]. Unfortunately, citizens almost invariably have no direct influence on the complex and multidimensional processes of shaping the healthcare policies, as they are not developed by health experts, economists, and healthcare administrators but instead decided upon by politicians [5], who almost without exception make empty promises and blame other, including medical professionals [6]. All this results in an atmosphere of grievance against medical professionals.

The aim of the article is to point at negative phenomena resulting from legal and psychological pressure on medical staff in the context of malpractice accusations, including so called defensive medicine and culture of blame, and then to shed light on their positive alternatives, especially no-blame compensation mechanisms, with their benefits. 


\section{A culture of blame}

Patients' grievances particularly involve physicians and result in an increasing number of legal claims in criminal and civil state courts, as well as in medical professional self-governments' courts. In Poland in 2015, there were 3,394 cases concerning alleged medical errors processed by the offices of the regional state prosecutors (Polish: prokuratura okręgowa); that number increased to 5,739 in 2016. The comparative organs of Polish chambers of physicians (Polish: rzecznik odpowiedzialności zawodowej lekarzy przy okręgowej izbie lekarskiej) processed 2,998 similar cases in 2017 and 3,236 in 2018 [7].

Politicians seeking votes often respond to the expectations of the general public by introducing harsher legal regulations targeting delinquent or negligent medical professionals. A recent vivid example of this approach is the change in the sentencing rules for unintentionally causing another's death, which was originally punishable by imprisonment for a period ranging from three months to five years (article 155 of the Polish Criminal Code, before amendment) [8]. The amendment was proposed by the government, has been passed by both chambers of parliament, and is scheduled to come into force on 13 September 2019 [9]. Article 1, point 56 of the Act extends the period of imprisonment to one to ten years (article 155 paragraph 1 of the Polish Criminal Code, as amended). This has focused medical professionals' attention, as the criminal courts have sometimes found physicians who have made a medical mistake guilty of this crime. The new law almost entirely eliminates the option previously available to courts of suspending the sentence, which is possible only for sentences of up to one year (article 69 of the Polish Criminal Code); this could thus be availed of only by those sentenced to the shortest possible term. Moreover, the new law by default does not allow a suspended sentence with probation in cases involving the death of more than one person. This can easily happen to an obstetrician if a pregnant woman and her neonate child both die, in which case the doctor faces a sentence of two to fifteen years (article 155, paragraph 2 of the Polish Penal Code, as amended). The amendment also prevents a sentence of imprisonment being converted into a less severe punishment, such as restriction of liberty or a fine, which is allowed only in the case of crimes subject to imprisonment of up to eight years (article 37a of the Polish Criminal Code). The amendment to the Criminal Code [9] has not yet been signed by the President of Poland, who instead sent it to the Constitutional Tribunal, which rules on the constitutionality of the state's activities. The amendment has not yet come into force, but even if the Constitutional Tribunal accepts its constitutionality, the government is considering immediately amending it again [10] to undo the damage, by altering the sentencing period in article 155, paragraph 1 [9] from "one to ten years" into "six months to eight years". These changes would restore flexibility to the courts, allowing them to impose suspended sentences and to convert prison sentences into less severe punishments [10]. It is not surprising that medical professionals have reacted nervously to this protracted legal instability.

\section{Defensive medicine}

The term "defensive medicine" describes adjustments made by medical staff to their professional activities primarily to secure themselves from claims, especially legal malpractice lawsuits, and not to benefit the patient. Such defensive medicine involves two main strategies: risk reduction and risk avoidance [11]. Risk reduction is encompassed by the narrow but still accurate definition of defensive medicine from the late 1970s: "the use of diagnostic and end-treatment measures explicitly for the purposes of averting malpractice suits" [12]. Defensive medicine may also make physicians follow medical standards in a rigid, inconsiderate, or merely formal manner, despite the fact that these are primarily meant to be "standardized specifications for managing particular clinical problems and are intended to improve the outcomes of medical care by increasing adherence to standards of care, meant to make medicine more cost-effective by eliminating unnecessary procedures" [13]. Although this may negligible compared to the overall scale of overprescribing and overtreatment that are driving up healthcare costs worldwide [14], it is estimated that medically unjustified procedures driven by fears of malpractice suits account for even as much as $20 \%$ of total healthcare costs. Primary care physicians are the greatest contributors in that they tend to overcautiously order otherwise unneeded hospitalizations, generating significant secondary costs [15]. To avoid complaints from patients, almost all general practitioners have begun to adopt defensive medical practices, with over half performing more diagnostic testing, referrals, follow-ups, and note taking $[16,17]$. More risk-averse medical professionals tend to generate greater expenditure when presented with the same case mix [18]. Another problem associated with defensive medicine is the increasing exposure of patients to additional health risks related to unnecessary or excessively aggressive medical procedures, which allow physicians to maintain more control over the situation. A vivid example of this is the positive correlation between the level of malpractice claims perceived by physicians and the increase in deliveries by cesarean section [19]. Although risk avoidance seems less popular than risk reduction [11], malpractice litigation, especially if experienced personally, makes physicians more likely to avoid certain types of patients, to retire early or to switch to a nonclinical position or may even discourage young people from choosing medical careers [20]. The overcautious attitude of defensive medicine may make medical staff avoid some procedures that are potentially beneficial to patients but have an elevated risk; they may even avoid treating patients who are considered to be high risk [11]. Overall, defensive medicine presents a highly detrimental phenomenon that not only increases medical service expenses and limits their general availability, but also makes expected and achievable health benefits unavailable to patients; sometimes it even unnecessary increases hazards to health.

The relation between defensive medicine, litigious behaviors, and medical malpractice insurance should be considered a social game, where responses to clinical and legal risks shape the interactions between healthcare providers and patients. In the worst-case, lose-lose scenario, patients sue physicians and demand compensation when medical treatment fails. Physicians, on the other hand, strive to prevent negligence charges by practicing medicine overcautiously or by buying expensive medical malpractice insurance, which transfers the risk of litigation from the physician to the insurer [21]. In turn, the physicians are likely to shift this additional expense into the costs of their services. Consequently, after considering the obvious fact that patients cover overall medical care costs - directly or indirectly - it becomes an obvious example of a vicious circle.

It may be surprisingly difficult to avoid this lose-lose scenario, and some common-sense interventions may give counterintuitive results. Increasing the average compensation granted by courts to patients in malpractice lawsuits, though seemingly a positive measure, only acts to escalate defensive medicine and, perhaps paradoxically, results in patients being treated with safer but less effective methods, leading to a loss of health benefits. Moreover, the again seemingly positive increase in the number of physicians who found guilty of malpractice may paradoxically backfire by accelerating the spread of defensive medicine, especially when court rulings seem to be inappropriate or affect physicians who already practice defensive medicine [22]. Surprisingly, even improving clinical safety - a seemingly universal solution to every problem in medicine - does not improve situation here, as it neither decreases the number of patients who sue their physicians nor limits the spread of defensive medicine. This clearly suggests that the classic approaches - based on complex legal proceedings, the patient's right to claim large 
compensation, and the physicians' reliance on expensive liability insurance - have already reached a dead end. It would thus seem that it is time for the state to become involved [23], especially given that as many as three quarters of surveyed physicians stated that they practice defensive medicine [24], making it a serious public health problem.

There are significant differences in the prevalence of risk-aversion attitudes among physicians practicing the same medical specialty in different countries, and this depends on differences in doctor-patient relationship patterns and in medical education systems [25]. It is commonly held that the most effective method of preventing malpractice lawsuits is to restore or improve communication between medical professionals and their patients [26]. However, this is severely hindered by the conflict of interests resulting from the current "blame and cover-up" climate. The alternative would seem to be to introduce a "blame-free culture" into healthcare, one based on openness and fairness. This might be supposed to better foster medical safety by encouraging full disclosure of flaws in the design of equipment, systems, procedures, and facilities, as well as the human-related factors underlying both near misses and incidents of different levels of severity, ranging from every-day minor slips and slight lapses to grave mistakes and serious violations [27]. A violation may be defined as a deviation from the approved procedures, standards, or rules, and may either result from ignorance or from a deliberate intention to act in a given way, though without any intention of leading to a negative outcome. Indeed, such approaches may result from system faults that lead to work environments and circumstances that make it impossible for the workers to get the job done without breaking some rules. However, everyday violations much more commonly result from the attitudes of particular individuals: the routine cutting of corners is common in work environments where the reasons for procedures, standards, or rules are not sufficiently clear or convincing to workers, where compliance is not sufficiently rewarded, and violations are only rarely sanctioned. In contrast, so-called optimizing violations involve personal goals, such as greed, which lead to a person's action or omission $[28,29]$.

\section{Blame-free compensation}

In 1974, in order to slow the rising wave of malpractice litigations, New Zealand introduced a system of government-funded compensation for medical injuries. In 2005, this was expanded to cover all cases of treatment-related injuries [30]. Since 1996, patients have a right to report alleged malpractice to an independent commissioner who investigates such cases and acts as a public advocate for healthcare safety [31]. In comparison to the tort-based system, the system of government-funded compensations has proved to be more effective in dealing with complaints and making medical service accountable; this has resulted in more timely compensations granted to a greater number of affected patients [30]. In Poland too, the Patient Rights and Ombudsman Act of 6 November 2008 [32], with its 2011 amendment [33], introduced a new way for patients who have suffered medical harm (or their estate; henceforth "the claimant") to seek compensation without costly, time-consuming, blame-based court proceedings.

The provisions of the Act are available only to those who, as a result of hospitalization, have been infected by a biological pathogen or have suffered bodily trauma, a health disturbance, or death resulting from a so-called "medical incident" (Polish: zdarzenie medyczne). This term encompasses acts that are in disagreement with current medical knowledge, including diagnosis leading to improper treatment or a delay in proper treatment that allows the disease to progress; improper treatments, including surgical procedures; or improper applications of medical products or device [32].
The bodies responsible for these cases are the medical incident boards of each of the 16 voivodships that make up the territory of Poland (Polish: wojewódzka komisja do spraw orzekania o zdarzeniach medycznych; henceforth "the Board") [32]. Although the proceedings of the Boards are extrajudicial [34], they can be considered to have a quasicourt status [35] and to be a part of the system of administrative protection of patients' rights. They are nonetheless voluntary, conciliatory, and mediatory in character [36]. Each Board is made up of 16 members, half of whom are medical professionals; the other half consists of legal professionals. The process of appointing the Boards is complex; before being appointed for a six-year term by the voivodship governor, four members are put forward by the local chamber of physicians, four by the local association of legal professionals, and six by local patients' rights organizations; one is appointed directly by the Minister for Health, and one more by the Ombudsman for Patients' Rights. Each case is dealt with by a team of four Board members (two medical and two legal professionals). They receive from the State remuneration of 470 złoty (or about $€ 104$ ) per sitting and reimbursement for travel expenses; proceedings are secret and cannot take place if compensation has already been granted by court. Proceedings can be suspended for the duration of a related criminal case or professional disciplinary proceeding by the chamber of physicians [32].

A medical incident report (Polish: wniosek o ustalenie zdarzenia medycznego; henceforth "report") can be filed up to one year after the claimant has learned about the possible medical incident, but must also be filed within three years from the date of the incident itself. The only exception is if the patient is dead, in which case the time is counted from the probate settlement date. A report needs to describe the incident, provide supporting evidence, and suggest compensation; this is capped by law at 100,000 złoty (or about $€ 22,000$ ) for a patient who has been infected by a biological pathogen or has suffered bodily trauma or a health disturbance, and at 300,000 złoty (or about $€ 66,000$ ) if the patient died [32].

Once a report has been filed with the respective Board, it is forwarded to the head of the relevant hospital and its insurance company, who have 30 days to decide upon it. If they fail to respond within this period, it is assumed that they accept the report in its entirety, including the accuracy of the circumstances described and the appropriateness of the compensation [32].

If the hospital and insurance company disagree with the report within 30 days, the Board must decide whether the case resulted in a material or a nonmaterial loss and whether it fits the definition of a medical incident. The claimant and the representatives of the hospital and insurance company may participate willingly in the proceedings of the Board. The Board is also entitled to summon them and any people working at the hospital, including medical staff, to require additional explanations and information relevant to the Board's proceedings. The evidence provided by the claimant, the hospital, and the insurance company are then analyzed by the Board. The Board is also entitled to access to medical files from the hospital and to inspect its premises and equipment. It can also request an opinion from a professional expert witness. The proceedings of the Board are not supposed to last for longer than four months; they end in the council sitting where presence of all four members of the Board team and a $75 \%$ majority is required for a binding decision. The decision of the Board is presented as a written document together with an explanatory statement that must be made available to all parties within seven days. It is only on the basis of these that the parties can appeal the Board's decision. If at this stage the Board does not determine that a medical incident occurred, the proceedings end [32].

If the Board establishes that medical incident did occur, and there is no further opportunity of an appeal, the decision becomes binding on the insurance company which then, within 30 days, needs to present the claimant with a compensation prop- 
osition; the amount proposed needs to be under the caps specified in the Act. If the insurance company fails to make a proposition within the time allotted, the compensation specified in the report becomes binding on the insurance company [32].

Assuming the insurance company has made a timely proposal on compensation, the claimant has seven days to accept or reject it. If the claimant accepts it, he or she becomes entitled to receive the proposed compensation from the insurance company. In accepting the offer, the claimant makes a binding statement that he or she abandons any future claims of financial compensation for consequences of the medical incident that were known at the moment of filing the report [32].

If the claimant turns down the proposition of compensation presented by the insurance company, he or she can proceed with legal proceedings in criminal or civil courts. For the purposes of civil proceedings, the fact that the insurance company has made an offer of compensation during Board proceedings is not considered to constitute an acceptance of the claim [32].

The cost of filing the report are low and fixed (200 złoty, or about €44). However, the overall costs of the proceedings are a bit higher, as they also include the cost of professional expert witnesses' opinions (typically 300-450 złoty, or about €65$-€ 100)$, reimbursements for people summoned by the Board for lost income (a flat-rate of around 150 złoty, or about €33), for travel (85 złoty, or about €19 per $100 \mathrm{~km}$ covered), and for accommodation (at 35 złoty, or about €8 per night) [37]. The hospital or its insurance company typically covers those costs, except in cases where the Board has not established a medical incident; then the costs of the proceedings need to be covered by the claimant [32]. However, in comparison to the average costs of court proceedings, these costs are still negligible, and under certain circumstances the Board can even waive the requirement to cover the costs partially or wholly, based on the principle of equity [38].

To date, the legal mechanism described here seems to be less effective than was hoped. It has not proven too popular: in 2017, there were 828 reports filed in the whole country [39] compared with several thousand medical malpractice-related cases processed by organs serving various court systems [7]. In particular, the Board team's proceedings often last longer than four months, and they tend to slow down at different stages. Additionally, the compensation proposed by the insurance companies tends to be too small to be attractive to claimants [40]. According to the report of members of the 2012-2017 Lower Silesian Medical Incidents Board, the major faults of the current legal regulations in practice were a lack of flexibility in staffing Board teams given the required competences of the medical professionals in relation to the characteristics of the particular case, or in response to various circumstances that render the members temporarily inactive, including leave related to illness or education; and the lack of means to force a witness sum- moned by the Board team to attend its sitting, resulting in their frequent absence. Other obstacles to the Boards' proceedings included negligent preparation of the required documents by hospitals and illegible or incomplete medical files. However, the Boards' procedures are nonetheless faster, cheaper, and less formal than court proceedings. Moreover, unlike in courts, the filing party does not need to provide decisive evidence of the report's accuracy, but needs only back up the claim adequately [37].

At present, it sometimes seems much easier to place all the blame on a faulty system than to attempt to identify the particular individuals who failed to meet their professional responsibilities. It seems that one of the public's major difficulties with the blame-free approach is the failure to understand that the need to separate personal responsibility from institutional accountability does not mean abolishing personal responsibility. It rather means shifting the emphasis from punishing individual for past events to ensuring improvements in the future. Consequently, the personal responsibility of medical staff for incompetence and unethical or unprofessional conduct needs to be separated from the institutional accountability of medical service providers for incidents related to faults in the organization of the system. Such faults need to be disclosed freely to allow improvements in the healthcare organization and to granting claimants appropriate compensation [29]. Blame-free mechanisms of dealing with medical mistakes tend to evoke public's concern about the lessening of professional accountability in this vitally important field, but it in fact helps make the public's idealistic image, and inflated expectations, of medical professionals face a reality check [41].

\section{Conclusions}

The legal and psychological pressure on medical staff in the context of malpractice accusations causes important negative phenomena, including so called defensive medicine and culture of blame, that generate multi-level costs both on the side of the society as a whole and the medical staff. In response to that, several countries are currently experimenting with alternative approaches, including no-blame compensation mechanisms. As of 2011, Poland has made a significant step towards introducing a blame-free culture in medicine by implementing the legal foundations of an administration-based out-of-court conciliatory procedure aimed at rapid, cheap, and convenient provision of compensation for patients who have suffered harm at hospitals. Unfortunately, it is not always easy to make even good ideas and regulations function correctly and obtain the popularity they deserve. For optimal results, the no-blame compensation mechanisms need to address problems not only of the medical staff working at hospitals but also of all other medical professionals, including primary care physicians.

Source of funding: This work was funded from the authors' own resources.

Conflicts of interest: The authors declare no conflicts of interest.

\section{References}

1. Toraldo D, Vergari U, Toraldo M. Medical malpractice, defensive medicine and role of the media in Italy. Multidiscip Respir Med 2015; 10(1): 12, doi: 10.1186/s40248-015-0006-3.

2. Zwinczewska H, Rozwadowska J, Traczyk A, et al. Knowledge on the subject of human physiology among Polish high school students - a cross-sectional study. Przegl Lek 2014; 71(12): 666-671.

3. Paplicki M, Susło R, Dopierała K, et al. Systemic aspects of securing the health safety of the elderly. Fam Med Prim Care Rev 2018; 20(3): 267-270, doi: 10.5114/fmpcr.2018.78272.

4. Rasanathan K, Posayanonda T, Birmingham M, et al. Innovation and participation for healthy public policy: the first National Health Assembly in Thailand. Health Expect 2012; 15(1): 87-96, doi: 10.1111/j.1369-7625.2010.00656.x.

5. Chuengsatiansup K, Tengrang K, Posayanonda T, et al. Citizens' jury and elder care: public participation and deliberation in long-term care policy in Thailand. J Aging Soc Policy 2019; 31(4): 378-392, doi: 10.1080/08959420.2018.1442110.

6. Badurek S. Trudno wierzyć rządowi. Gazeta Lekarska 2019; 7-8: 66. Available from URL: https://papier.gazetalekarska.pl/pdf/Gazeta_ Lekarska_07-08_2019.pdf (in Polish). 
7. Tomczak M. Błędne koło. Gazeta Lekarska 2019; 7-8: 18-21. Available from URL: https://papier.gazetalekarska.pl/pdf/Gazeta_Lekarska_07-08_2019.pdf (in Polish).

8. Ustawa z dnia 6 czerwca 1997 r. Kodeks karny (Dz.U. 1997 nr 88 poz. 553 with amendments) (in Polish).

9. Ustawa z dnia 13 czerwca 2019 r. o zmianie ustawy - Kodeks karny oraz niektórych innych ustaw [cited 20.08.2019]. Available from URL: https://orka.sejm.gov.pl/proc8.nsf/ustawy/3451_u.htm (in Polish).

10. Autopoprawka do projektu ustawy o zmianie ustawy Kodeks karny (druk nr 3386) Premier.gov.pl 18.06.2019 [cited 20.08.2019]. Available from URL: https://www.premier.gov.pl/wydarzenia/decyzje-rzadu/autopoprawka-do-projektu-ustawy-o-zmianie-ustawy-kodekskarny-druk-nr-3386.html (in Polish).

11. Weisman C, Morlock L, Teitelbaum M, et al. Practice changes in response to the malpractice litigation climate: results of a maryland physician survey. Medical Care 1989; 27(1): 16-24, doi: 10.1097/00005650-198901000-00002.

12. Tancredi L, Barondess J. The problem of defensive medicine. Science 1978; 200(4344): 879-882, doi: 10.1126/science.644329.

13. Brennan T. Practice guidelines and malpractice litigation: collision or cohesion? J Health Polit Policy Law 1991; 16(1): 67-85, doi: 10.1215/03616878-16-1-67.

14. Hermer L, Brody H. Defensive medicine, cost containment, and reform. J Gen Intern Med 2010; 25(5): 470-473, doi: 10.1007/s11606010-1259-3.

15. Reschovsky J. Saiontz-Martinez C. Malpractice claim fears and the costs of treating medicare patients: a new approach to estimating the costs of defensive medicine. Health Serv Res 2018; 53(3): 1498-1516, doi: 10.1111/1475-6773.12660.

16. Summerton N. Positive and negative factors in defensive medicine: a questionnaire study of general practitioners. BMJ 1995; 310(6971): 27, doi: https://doi.org/10.1136/bmj.310.6971.27.

17. Studdert D, Mello M, Sage W, et al. Defensive medicine among high-risk specialist physicians in a volatile malpractice environment. JAMA 2005; 293(21): 2609-2617, doi: 10.1001/jama.293.21.2609.

18. Fiscella K, Franks P, Zwanziger J. et al. Risk aversion and costs: a comparison of family physicians and general internists. $J$ Fam Pract 2000; 49(1): 12-18.

19. Localio A, Lawthers A, Bengtson J, et al. Relationship between malpractice claims and cesarean delivery. JAMA 1993; 269(3): 366-373, doi: 10.1001/jama.1993.03500030064034.

20. Charles S, Wilbert J, Franke K. Sued and nonsued physicians' self-reported reactions to malpractice litigation. Am J Psychiatry 1985; 142(4): 437-440, doi: 10.1176/ajp.142.4.437.

21. Antoci A, Fiori Maccioni A, Galeotti M, et al. Defensive medicine, liability insurance and malpractice litigation in an evolutionary model. Nonlinear Anal-Real 2019; 47: 414-435, doi: 10.1016/j.nonrwa.2018.08.012.

22. Antoci A, Fiori Maccioni A, Russu P. Medical practice and malpractice litigation in an evolutionary context. J Evol Econ 2018; 28(4): 915-928, doi: 10.1007/s00191-018-0578-0.

23. Antoci A, Fiori Maccioni A, Russu P. The ecology of defensive medicine and malpractice litigation. PLoS ONE 2016; 11(3): e0150523, doi: 10.1371/journal.pone.0150523.

24. Passmore K, Leung W. Defensive practice among psychiatrists: a questionnaire survey. Postgrad Med J 2002; 78(925): 671-673, doi: 10.1136/pmj.78.925.671.

25. Grol R, Whitfield M, De Maeseneer J, et al. Attitudes to risk taking in medical decision making among British, Dutch and Belgian general practitioners. BrJ Gen Pract 1990; 40(333): 134-136.

26. Shapiro R, Simpson D, Lawrence S, et al. A survey of sued and nonsued physicians and suing patients. Arch Intern Med 1989; 149(10): 2190-2196, doi: 10.1001/archinte.1989.00390100028008.

27. Lilleyman J. A blame-free culture in the NHS: quixotic notion or achievable ambition? Perfusion 2005; 20(4): 233, doi: 10.1191/0267659105pf812oa.

28. Reason J. Managing the risks of organisational accidents. London, New York: Routlege; 1997.

29. Walton M. Creating a "no blame" culture: have we got the balance right? Qual Saf Health Care 2004; 13(3): 163-164, doi: 10.1136/ qshc.2004.010959.

30. Bismark M, Paterson R. No-fault compensation in New Zealand: harmonizing injury compensation, provider accountability, and patient safety. Health Affairs 2006; 25(1): 278-283, doi: 10.1377/hlthaff.25.1.278.

31. Paterson R. The patients' complaints system in New Zealand. Health Affairs 2002; 21(3): 70-79, doi: 10.1377/hlthaff.21.3.70.

32. Ustawa z dnia 6 listopada 2008 r. o prawach pacjenta i Rzeczniku Praw Pacjenta (Dz.U. 2009 nr 52 poz. 417, ze zm.) (in Polish).

33. Ustawa z dnia 28 kwietnia 2011 r. o zmianie ustawy o prawach pacjenta i Rzeczniku Praw Pacjenta oraz ustawy o ubezpieczeniach obowiązkowych, Ubezpieczeniowym Funduszu Gwarancyjnym i Polskim Biurze Ubezpieczycieli Komunikacyjnych (Dz.U. 2011 nr 113 poz. 860) (in Polish).

34. Stefanek K. Komisje wojewódzkie do spraw orzekania o zdarzeniach medycznych. Państ Społecz 2015; 15(1): $97-109$ (in Polish).

35. Sadowska J. Status prawny wojewódzkich komisji do spraw orzekania o zdarzeniach medycznych. Przeglqqd Prawniczy, Ekonomiczny i Społeczny 2014; 2: 84-93 (in Polish).

36. Jacek A, Ożóg K. Ochrona administracyjna praw pacjenta. Prz Med Uniw Rzesz Inst Leków 2015; 13(3): $306-317$ (in Polish).

37. Haczkowska A. Sprawozdanie z działalności Wojewódzkiej Komisji do Spraw Orzekania o Zdarzeniach Medycznych we Wrocławiu za okres 2012-2017 [cited 23.08.2019]. Available from URL: http://duw.pl/download/1/27616/SprawozdaniezdzialalanosciKomisjiwlatach2012-201754.doc (in Polish).

38. Gładysz S. Podsumowanie sześciomiesięcznej działalności Wojewódzkiej Komisji ds. Orzekania o Zdarzeniach Medycznych we Wrocławiu. Wady i zalety nowej procedury orzekania o błędach medycznych [cited 23.08.2019]. Available from URL: https://www.i-kancelaria. pl/publikacje/podsumowanie-szesciomiesiecznej-dzialalnosci-wojewodzkiej-komisji-ds-orzekania-o-zdarzeniach-medycznych-wewroclawiu-wady-i-zalety-nowej-procedury-orzekania-o-bledach-medycznych/ (in Polish).

39. 828 wniosków do wojewódzkich komisji ds. orzekania o zdarzeniach medycznych. Polityka Zdrowotna 18.08.2018 [cited 23.08.2019]. Available from URL: https://www.politykazdrowotna.com/35451,828-wnioskow-do-wojewodzkich-komisji-ds-orzekania-o-zdarzeniach-medycznych (in Polish).

40. Najwyższa Izba Kontroli. Informacja o wynikach kontroli: pozasądowe dochodzenie roszczeń przez pacjentów. KZD.430.005.2018. NIK 31.10.2018 [cited 23.08.2019]. Available from URL: https://www.nik.gov.pl/plik/id,18515,vp,21114.pdf (in Polish).

41. Babcock R, Gillett G. Error and accountability in a no-fault system: maintaining professionalism. J Law Med 2016; 24(2): 303-313.

Tables: 0

Figures: 0

References: 41 
Received: 2.09.2019

Reviewed: 15.03 .2020

Accepted: 4.06.2020

Address for correspondence:

Robert Susło, MD, PhD, MA

Zakład Gerontologii

Katedra Zdrowia Publicznego

Wydział Nauk o Zdrowiu

Uniwersytet Medyczny we Wrocławiu

ul. Bartla 5

51-618 Wrocław

Polska

Tel.: +48 71 345-93-24

E-mail: robert.suslo@umed.wroc.pl 